\title{
Effect of Budget Deficit on Trade Deficit in Pakistan (A Time Series Analysis)
}

\author{
Muhammad Kashif Tufail ${ }^{1}$, Dr. Sofia Anwar ${ }^{2}$, Syed Hassan raza ${ }^{3}$, Khawar Abbas ${ }^{4, *}$ \\ ${ }^{1}$ Assistant professor Department of Economics, Bahauddinzakariya university Lahore campus, Pakistan \\ ${ }^{2}$ Chairman/Professor Departments of Economics, G.C University Faisalabad, Pakistan \\ ${ }^{3}$ Lecturer of Economics at National University of modern languages Faisalabad, Pakistan \\ ${ }^{4}$ Research scholar of M. Phill Economics, G.C University Faisalabad, Pakistan \\ *Corresponding author: Khawar.economist@hotmail.com
}

Received March 28, 2014; Revised April 23, 2014; Accepted May 05, 2014

\begin{abstract}
The study examined the relationship between Budget deficit and Trade deficit for the economy of Pakistan. Time series data was used from the period 1972 to 2011. Augmented Dickey Fuller Test used to check the stationary of the variables and found that all variables were stationary at first difference. Johansen Co-integration used to find the long relationship and found that budget deficit has positive effect on trade deficit in long run. Error correction model indicated the convergence or divergence of the economy in short run to long run. The ECM results showed that $30.88 \%$ convergence occur within year. Granger causality test used to check the direction of causality between the budget deficit and trade deficit and results was indicated that there is bi-directional between the variables.
\end{abstract}

Keywords: budget deficit, trade deficit, $A D F$, johansen co-integration, error correction model, granger casualty

Cite This Article: Muhammad Kashif Tufail, Dr. Sofia Anwar, Syed Hassan raza, and Khawar Abbas, "Effect of Budget Deficit on Trade Deficit in Pakistan (A Time Series Analysis)." Journal of Finance and Economics, vol. 2, no. 5 (2014): 145-148. doi: 10.12691/jfe-2-5-2.

\section{Introduction}

The Budget deficit and trade deficit i.e. twin deficit have very important role in any economy. Many recent studies argue in favor of the close relationship between the twin deficits i.e. the Keynesian proposition see (Darrat [3], Abell [1], Zietz and Pemberton [21], Vamvoukas [19]. While the others economist like \{Evans [8], Dewald and Ulan[4], Enders and Lee [7] and Kim [17] were in support of the Ricardian equivalence that the relationship between the budget deficit and trade deficit is not correlated.

The problem of twin deficits has been one of the most disputed issues in economics. Different schools of thoughts have different ideas about the relationship between budget deficits and current account deficits in both developed and developing countries. Following McCoskey and Kao [18], define twin deficits as a long-run (positive) relationship between the current account and the budget deficit, including some other factors. The study of twin deficit phenomena got serious attention from researchers due to the reason that in most of the situation, twin deficits may lead to economic harms and hurt economic growth. The link between an economy's current account deficit and its budget deficit delighted wide academic debate and empirical testing over the decades.

According to Friedman [11], when deficits are used rationally, they are means of financing growth and reducing unemployment. The relationship between the budget deficit and current account deficit has examined by many economists. Researchers such as Fleming [11], Kawai [16], Hutchison and Piggott [14], Vamvoukas [19], McCoskey and Kao [18], found support for the conventional view that a worsening budget deficit stimulates an increase in current account deficit. According to Hutchison and charless [14] an increase in the budget deficit is likely to raise domestic real interest rates and subsequently would increase the trade deficit, but

In Pakistan, the debate to explain the dynamics of twin deficits started since its independence. A number of studies have been carried out regarding these issues and researcher made separate analysis related to Micro level and Macro level with the relevance of economic growth. Further, in Pakistan due to the free trade, the steps of the WTO liberalization of trade, there is a need to understand the relationship between the fiscal and trade deficit.

\subsection{Objectives of the Study}

The present study is devoted to examine the relationship between budget deficit and trade deficit in the economy of Pakistan. The objectives of my research work are as follows:

1. Explore the Long-run relationship between budget deficit and trade deficit.

2. To investigate Short-run relationship between budget deficit and trade deficit.

3. To find out the factors affecting the relationship between budget deficit and trade deficit. 


\section{Policy recommendations.}

\section{Review of Literature}

Zamanzadeh and Mehrara [20] found long run association between current government budget deficit on non-oil current account deficit of Iran for the data related to 1959-2007 through co-integration technique. The variables used in this study include gross domestic product, non-oil export, aggregate import, government consuming expenditures and government tax revenue. A bidirectional causal relationship was also witnessed. So estimated long run coefficient confirms Keynesian's view or existence of twin deficits in the Iranian economy. Aqeel and Nishat [2] suggested that budget deficit has powerful long run effects on current account deficit in Pakistan. No relationship was found between the twin deficits through the interest rate relationship and no co-integration between interest rate and the twin deficits was found. The long run effect of current account deficit on budget shortfall was positive. There was also no evidence of short run causality from current account balance to fiscal deficit. Hakro [13] used vector autoregressive model on time series data from 1948 to 2005, reveal the causal relationship between twin deficits and other macroeconomic variables in Pakistan. The model suggested that changes in interest rates are not responsible for the prior changes in budget and trade deficits. According to study another significant aspect was the presence of thin capital markets in underdeveloped countries and the credit markets were influenced by government political decision processes. Capital flows lead to effect exchange rate and the relationship between budget deficits and exchange rates are also present. So the study has offered reliable evidence about confirmation of the Keynesian's theory and acceptation of twin deficit hypothesis by lying statistical techniques.

\section{Material and Methods}

This section briefly outlines the empirical setup by illustrating data and econometric estimation approaches used in this dissertation.

Time series data from the period 1972 to 2011 were used in this study. The variables are used Trade Deficit (TD), Budget Deficit (BD), Trade Openness (OPENN), Exchange Rate (ER), Real GDP and Financial Development (FD).

\subsection{Model of the Study}

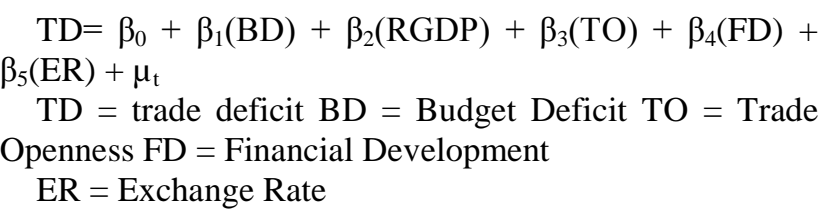

\subsection{Unit Root Test}

Stationary, is determined as a high quality of a procedure in which the mathematical factors (mean and conventional deviation) of the procedure do not modify with time. Stationary process is relative term not an absolute term. Stationary process is mostly seen only in long run sample size in which frequency of the data is high. Unit root test check the stationary of the model. On the integrated order of the variable we decide the appropriate technique to find the relationship between the variable. There are different test to check the integrated order of the variables. In this study Augmented Dickey Fuller (ADF) was used. The mathematical form of the $\mathrm{ADF}$ is

$$
\begin{aligned}
& \Delta y_{t}=\alpha+\beta t+\gamma y_{t-1}+\delta_{1} \Delta y_{t-1} \\
& +\ldots+\delta_{p-1} \Delta y_{t-p+1}+\varepsilon_{t}
\end{aligned}
$$

\subsection{Johansen Co-integration}

It tells that long run relationship exists or not. Johansen co-integration used when the integrated order of the variable same i.e. I (1). It fellows two test

1. Rank Test;

2. Maximum Eigen Values Test.

\subsection{Error Correction Model}

To check short run relationship this model is used. Sargan initially made use of this model and then made popular by Granger and Engle which necessarily mean of fixing the behavior of short run for variable of economics with its behavior of long run.

In $\mathrm{ECM} \Delta \mathrm{Yt}=\beta \mathrm{o}+\beta 1 \Delta \mathrm{Xt}+\pi \mu_{\mathrm{t}-1}+\mathrm{e}_{\mathrm{t}}$

$\pi=$ Error correction co-efficient

\section{Results and Discussion}

Table 1. Augmented Dickey Fuller (ADF) at level

\begin{tabular}{|c|c|c|}
\hline Variables & ADF Test Statistics & Probability \\
\hline Ln (TD) & -1.97 & 0.5930 \\
\hline Ln (BD) & -3.17 & 0.1066 \\
\hline Ln (FD) & -0.66 & 0.9688 \\
\hline Ln (ER) & -2.69 & 0.2460 \\
\hline Ln (Trade Openness) & -2.51 & 0.3197 \\
\hline Ln (RGDP) & -1.07 & 0.9200 \\
\hline
\end{tabular}

Note: $-4.26,-3.55,-3.21$ are critical avalues at $1 \%, 5 \%$ and $10 \%$ significance level respectively. The above table shows results of ADF test of the variable at a level which indicate all variables are nonstationary at level.

Table 2. Augmented Dickey Fuller(ADF) Test at $1^{\text {st }}$ Difference

\begin{tabular}{|c|c|c|c|}
\hline Variables & ADF Test Statistics & Probability & Conclusion \\
\hline Ln (BD) & -5.82 & 0.0001 & $\mathrm{I}(1)$ \\
\hline Ln (FD) & -3.74 & 0.0316 & $\mathrm{I}(1)$ \\
\hline Ln (ER) & -3.90 & 0.0222 & $\mathrm{I}(1)$ \\
\hline Ln (Trade Openness) & -6.14 & 0.0001 & $\mathrm{I}(1)$ \\
\hline Ln (RGDP) & -4.76 & 0.0026 & $\mathrm{I}(1)$ \\
\hline
\end{tabular}

Source: $\mathrm{E}$ views 7

Note $-4.234,-3.54$ and -3.202 are critical values at $1 \%, 5 \%$ and $10 \%$ significance level respectively. The above table shows results of ADF test of the variable at first difference which indicates all variables are stationary at first difference.

Table 3. Granger Causality Test

\begin{tabular}{|c|c|c|c|}
\hline Null Hypothesis & Observations & $\begin{array}{c}\text { F- } \\
\text { Statistics }\end{array}$ & Probability \\
\hline $\begin{array}{c}\text { BD does not Granger Cause } \\
\text { TD }\end{array}$ & 35 & 9.44186 & 0.0008 \\
\hline $\begin{array}{c}\text { TD does not Granger Cause } \\
\text { BD }\end{array}$ & & 8.00105 & 0.0003 \\
\hline
\end{tabular}

Source: E views 7

The above table shows the result of Granger Causality Test. The first F-Statistics is 9.44186 which shows reject the Null hypothesis i.e. BD does not Granger Cause TD 
and the probability is 0.0008 which also indicates rejection of Null Hypothesis. The second value of FStatistics shows the rejection of Null Hypothesis i.e. TD does not Granger Cause BD and the probability is 0.0003 which also indicates the rejection of Null Hypothesis. The above results show there is a bi-directional causality between Trade Deficit and budget deficit.

\subsection{Johansen Co-integration}

Table 4. Trace Test Statistics

\begin{tabular}{|c|c|c|c|}
\hline Hypothized no of CE (s) & Eigen Values & Trace Statistics & 0.05 Critical Values \\
\hline None $*$ & 0.95 & 275.28 & 95.75 \\
\hline At most 1 $*$ & 0.83 & 172.34 & 69.81 \\
\hline At most 2 & 0.80 & 110.48 & 47.85 \\
\hline At most 3 & 0.63 & 55.20 & 29.79 \\
\hline At most 4 & 0.44 & 21.29 & 0.0000 \\
\hline At most 5 & 0.03 & 1.24 & 0.0000 \\
\hline
\end{tabular}

Source: E views 7

The above table shows the result of Trace test. The trace statistics is 275.2814 which indicate the rejection of none* hypothesis. Second trace statistics is 172.3400 and critical value is 69.81889 which also reject the hypothesis of at most $1^{*}$ and probability is 0.0000 which also shows

rejection of null hypothesis. All results show that there are five co-integration equations. That shows there is existence of long run relationship between trade deficit and budget.

Table 5. Maximum Eigenvalue test

\begin{tabular}{|c|c|c|c|c|}
\hline Hypothized no of CE (s) & Eigenvalues & Maximum Eigen Statistics & 0.05 Critical Values & Probability \\
\hline None * & 0.951572 & 102.9413 & 0.0000 \\
\hline At most 1 & 0.837867 & 61.85750 & 30.07757 \\
\hline At most 2 & 0.803241 & 55.27643 & 27.87687 \\
\hline At most 3 & 0.631170 & 33.91227 & 21.13162 \\
\hline At most 4 & 0.445501 & 20.04948 & 0.0000 \\
\hline At most 5 & 0.035937 & 1.244342 & 0.0000 \\
\hline
\end{tabular}

The above table shows the result of Maximum Eigenvalue. The Maximum Eigenvalue statistics is 102.9413 which indicate the rejection of none* hypothesis. The second Maximum Eigenvalue statistics is 61.85750 and critical value is 33.87687 which reject the hypothesis of at most $1^{*}$ and probability is 0.0000 which also shows rejection of null hypothesis. Similarly the Maximum Eigenvalue statistics of third Maximum Eigenvalue test is 55.27643 and the value of probability of this test at most 2* is 0.0000 which lead to reject the Null Hypothesis. The fourth Maximum Eigenvalue statistics is 33.91227 and critical value is 21.13162 which also reject the hypothesis of at most $3^{*}$ and probability is 0.0000 which also shows rejection of null hypothesis. The value of Maximum Eigenvalue statistics and critical value at most $4 *$ are 20.04948 and 14.26460 respectively with probability value of 0.0055 indicate that the null hypothesis rejected. The sixth Maximum Eigenvalue statistics is 1.244342 and critical value is 3.841466 which indicate the acceptance of null hypothesis and results of probability is 0.2646 which also shows that the null hypothesis accepted. All results show that there are five co-integration equations. That shows there is existence of long run relationship between the variables.

Table 6. Normalized Co-efficient

\begin{tabular}{|c|c|c|c|}
\hline Variable & Co-efficient & Standard Error & t-statistic \\
\hline Budget Deficit & 0.262343 & 0.06934 & 3.7834 \\
\hline Financial Development & -0.408366 & 0.07995 & -5.1069 \\
\hline Exchange Rate & -3.009558 & 0.20167 & -14.9280 \\
\hline Trade Openness & 2.390806 & 0.14420 & 16.5797 \\
\hline Real GDP & 1.269355 & 0.43559 & 2.9179 \\
\hline
\end{tabular}

The above table stated that the trade deficit is positively related to budget deficit in long run. The value of Beta coefficient indicated that trade deficit tend to increase by increasing the budget deficit at average proportion of about 0.262343 , which shows in long run that if there is $1 \%$ increase in budget deficit will tend to $0.262343 \%$ increase in trade deficit and t-statistics of co-efficient of budget deficit is 3.7834 , which indicate that budget deficit has significant effect on trade deficit in long run. The value of Beta coefficient of Financial Development is about -0.408366 , which that if there is $1 \%$ increase in Financial Development tends to decrease $0.408366 \%$ in trade deficit and t-statistics of co-efficient of Financial Development is -5.1069 , which results that Financial Development has significant effect on trade deficit in long run. The results of exchange rate also shows significant effect with beta coefficient -3.009558 on trade deficit. It means if there is $1 \%$ increase in the exchange rate leads to decrease the trade deficit by 3.009558. In the long run the results of trade openness also shows the positive and significant effect on trade deficit. The value of Beta coefficient of real GDP is 1.269355, which shows that in long run if there is $1 \%$ increase in real GDP results $1.269355 \%$ increase in trade deficit and t-statistics of coefficient of real GDP is 2.9179, which indicate that budget deficit has significant effect on trade deficit in long run.

Table 7. Error Correction Model

\begin{tabular}{|c|c|c|}
\hline \multicolumn{3}{|c|}{ Table 7. Error Correction Model } \\
\hline Eariable & Co-efficient & t-statistic \\
\hline ECM) & -0.308835 & -2.595378 \\
\hline
\end{tabular}

The above table presents estimated coefficient of error correction term. The estimated value of the coefficient of the error correction term shows that the system corrects its previous period's level of equilibrium within a year. For instance, the error term -0.308835 implies that $30.88 \%$ convergence occurs towards short run to long run in Pakistan within a year through changes in budget deficit, real GDP, financial development, trade openness and exchange rate.

\section{Conclusion}

The most important of this research study was to observe the long run as well as short run relationship 
between Budget deficit and Trade deficit. The results of Johansen Co-integration regression shows that budget deficit, trade openness, and real GDP have positive impact on trade deficit. On the other hand financial development and exchange rate negatively affect the trade deficit. The results of error correction model also indicate the existence of short run relationship among the variables.

\subsection{Policy Recommendations}

By keeping in view the above cited results and arguments, the research study proposed the following policy recommendations

1. For reducing trade deficit, Government adopt those policies which reduce budget deficit such as decrease its expenditures or increase the revenue from Taxes.

2. Financial development also very important for reducing the trade deficit for the economy of Pakistan.

\section{References}

[1] Abell, J.D. (1990). Twin Deficits During the 1980’s: An Empirical Investigation. Journal of Macroeconomics. 12: 81-92.

[2] Aqeel, A. and M. Nishat (2000). The Twin Deficits Phenomenon: Evidence from Pakistan. The Pakistan Development Review. 39 (4): (Winter 2000). 535-550.

[3] Darrat, A. F. (1988). Have Large Budget Deficits Caused Rising Trade Deficit? Southern Economic Journal. 54: 879-87.

[4] Dewold, W. G., and M. Ulan (1990) The Twin-Deficit Illusion. Cato Journal 10: 689-707.

[5] Dornbusch, Rudiger, (1976). Expectations and Exchange Rate Dynamics. Journal of Political Economy. 84: 101-19.

[6] Edwards, S. (2002). Debt relief and the current account: an analysis of the HIPC initiative, Working Paper

[7] Enders, W. and B. S. Lee (1990). Current Account and Budget Deficits; Twin or Distant Cousins? The Review of Economics and Statistics. 72: 373-81.
[8] Evans, P. (1988). Do Budget Deficits Affect the Current Account. Ohio State University. Unpublished Paper.

[9] Fatima, M. and M. A. Qazi (2011). Political Economy of Fiscal Reforms in the 1990s, The Pakistan Development Review 40 (4): (Winter 2011). 503-518.

[10] Fleming, M. J. (1962). Domestic Financial Policies under Fixed and Floating Exchange Rates IMF Staff Papers 9: 369-379.

[11] Friedman, B. M. (2000). What Have we Learned from the Reagan Deficits and Their Disaearance? National Bureau of Economic Research Working Paper Series.

[12] Guddington, J. T. and M. V. Jose (1986). Budget Deficits and the Current Account in the Presence of Classical Unemployment. Economic Journal. 96: 101-19.

[13] Hakro, A. N. (2009). Twin Deficits Causality Link-Evidence from Pakistan. International Research Journal of Finance and Economics, Issue 24, 54-70.

[14] Hutchison, M. M. and P. Charles (1984). Budget Deficits, Exchange Rates and the Current Account: Theory and U.S. Evidence. Federal Reserve Bank of San Francisco. Economic Revie. 5-25.

[15] Ibrahim T. and T. Aysit (2011). An Analysis of Political and Institutional Power Dispersion: The Case of Turkey.

[16] Kawai, M. (1985). Exchange Rates, the Current Account and Monetary - Fiscal Policies in the Short Run and in the Long Run. Oxford Economic Papers. 37: 391-425.

[17] Kim K. H. (1995). On the Long-run Determinants of the US Trade Balance: a Comment. Journal of Post Keynesian Economics. 17: 447-55.

[18] McCoskey, S. and K. Chihwa (1999). Comparing Panel Data Cointegration Tests with an A lication to the Twin Deficits Problem. Syracuse University. Mimeo.

[19] Vamvoukas, G. (1999). The Twin Deficits Phenomenon: Evidence from Greece. A lied Economics. 31: 1093-1100.

[20] Zamanzadeh, A and M. Mohsen (2011). Testing Twin Deficits Hypothesis in Iran Interdisciplinary Journal of Research in Business. 1 (9): 07-11.

[21] Zietz, J. and D. K. Pemberton (1990). The US Budget and Trade Deficits: A Simultaneous Equation Model Southern Economic Journal. 57: 23-34. 